www.jmscr.igmpublication.org
Impact Factor 3.79

ISSN (e)-2347-176x

crossref DOI: http://dx.doi.org/10.18535/jmscr/v3i9.33

Journal Of Medical Science And Clinical Research

\title{
Self Medicated Abortion- Care or Crime
}

\section{Authors \\ Dr Meena Jethani ${ }^{1}$, Dr Kalpana Yadav ${ }^{2}$, Dr Shilpi Muchhoria ${ }^{3}$, Dr Shubhangi Sharma ${ }^{4}$, Dr Monika ${ }^{5}$}

${ }^{1} 3$ rd Year Resident, Department of Obstetrics and Gynaecology, Shyam Shah Medical College Rewa ${ }^{2}$ Associate Professor and Head of Dept Obstetrics and Gynaecology, Shyam Shah Medical College Rewa

${ }^{3}$ MD Radiology, Senior Resident at BMHRC, Bhopal

${ }^{4,5} \mathrm{MBBS}$, Shyam Shah Medical College, Rewa

Email: jethanimeena24@gmail.com

\begin{abstract}
Now a days due to change in life style of young generation, misuse of Abortion pills are a one of the major problems of the society. Main aim of this study is to find out the incidence of self medicated abortion and outcome and complication associated with it. Present study is prospective descriptive hospital based study, carried out in the department of obstetrics and Gynaecology, S.S. Medical College and associated Gandhi Memorial Hospital, Rewa (M.P.) for 1 year from 1st july 2013 to 30th june 2014 on 323 patients. Data was collected and analysed. Self medication was more common in 20-29 yrs (55.4\%), which were mostly multiparous (88.3\%). The most common presenting complaint was bleeding per vaginum (43.62\%). Most common outcome was incomplete abortion (57.45\%), most common complication was moderate anaemia (45.75\%). Health care and health protection is every woman's reproductive right. Every woman must be counseled regarding advantages, drawbacks, risks and limitations of different methods of abortion. Prevention of unwanted pregnancy is the best way to prevent unsafe abortion. Hence, awareness on contraceptives and emergency contraceptives is must for all. Abortion is silent screan, we have to encourage safe practise like MTP by either medical or surgical means "TO MEET THE UNMET NEEDS OF WOMEN'S HEALTH" in this aspect.
\end{abstract}

\section{INTRODUCTION}

Each year an estimated 42 million pregnancies end in induced abortion, out of which 20 million are performed under unsafe condition. Unsafe abortion is responsible for $13 \%$ of maternal deaths worldwide $^{1}$.Now a days due to change in life style of young generation, misuse of Abortion pills are a one of the major problems of the society. The World Health Organization (WHO $)^{2}$ recommendations on medical abortion are restricted to early first trimester. The term 'self medication' is applied when patient, her husband, her relative or her friend has brought the abortion pill (for patient) over the counter without medical guidance /supervision/prescription. Antiprogesterone drugs such as Mifepristone (RU486), prostaglandins like Misoprostol have been approved by the United States Food \& Drug Administration (USFDA) for medical abortion $^{3}$.As per Medical Termination of 
Pregnancy (MTP) Act of India ${ }^{4}$, this method can only be administered by Gynaecologists and Registered Medical Practitioners.In current day scenario over the counter abortifacients are available as on demand. This is an emerging havoc to current day practitioners as many of time these lead to incomplete abortion, missed abortion, septic abortion, haemorrhage, shock and death.

Despite significant progress in comprehensive abortion care services in india, it has been perceived by the society that, medical abortions are extremely safe option even in hands of untrained personnel, leading to its over the counter dispensing and possibly increase in unsupervised terminations and life threatening complications ${ }^{5}$.

\section{Objective}

To find out incidence of self medication in abortion patients coming to Gandhi Medical Hospital, Rewa.

$>$ To find out incidences of outcome and complication of self medicated abortion.

\section{Material and Methods}

Present study is prospective descriptive hospital based study,carried out in the department of obstetrics and Gynaecology, S.S.M.C. and associated GMH, Rewa (M.P.) for 1 year from $1^{\text {st }}$ july 2013 to $30^{\text {th }}$ june 2014 data was collected from patients.

$>$ A preformed questonairre was given to 323 women admitted to gynaecology ward with diagnosis of any abortion and early pregnancy complication.

Data was collected and arranged and statistically analysed and results and conclusions were obtained.

\section{RESULTS}

Data of 323 admitted patients were collected, out of which $94(29.1 \%)$ took some kind of medication to terminate their pregnancy.
Table 1 Demographic details: $\mathrm{n}=94$

\begin{tabular}{|l|l|l|}
\hline AGE IN YEARS & No. & $\%$ \\
\hline$<19$ & 7 & 7.4 \\
\hline $20-29$ & 52 & 55.4 \\
\hline $30-39$ & 32 & 34 \\
\hline$>40$ & 3 & 3.2 \\
\hline MARITAL STATUS & & \\
\hline Married & 87 & 92.56 \\
\hline Unmarried & 7 & 7.44 \\
\hline EDUCATION & & \\
\hline Nil & 15 & 15.95 \\
\hline$<5$ std & 18 & 19.16 \\
\hline $6-12$ std & 30 & 31.92 \\
\hline$>12$ std & 31 & 32.97 \\
\hline GRAVIDA & & \\
\hline 1 & 11 & 11.7 \\
\hline 2 & 34 & 36.17 \\
\hline 3 or more & 49 & 52.13 \\
\hline
\end{tabular}

More than half, 52 (55.4\%) women were in age group of 20- 29 years and majority 87 (92.56\%) women were married. Uneducated women were $15(15.95 \%)$. Out of all women, more than half women $49(52.13 \%)$ were gravida three or more.

Table- II Period of gestation at pill intake $(n=94)$

\begin{tabular}{|l|c|c|}
\hline No.of weeks & No. & $\%$ \\
\hline$<6$ wks & 11 & 11.7 \\
\hline $6 w k+1 d$ to 9 wks & 45 & 47.87 \\
\hline 9wk +1d to $12 w k s$ & 23 & 24.47 \\
\hline 12wk+1d to $15 w k$ & 12 & 12.76 \\
\hline$>15 w k s$ & 3 & 3.2 \\
\hline
\end{tabular}

As shown above, 45(47.87\%) women took the abortion pill in $6+1$ weeks to 9 weeks from their LMP. Most of women took pills at more than 9 weeks

Table -III Drugs brought by

\begin{tabular}{|l|l|l|}
\hline & No. & $\%$ \\
\hline Self & 28 & 29.79 \\
\hline Husband & 19 & 20.21 \\
\hline Quack & 36 & 38.3 \\
\hline Nurses & 11 & 11.7 \\
\hline
\end{tabular}

Above table shows that in 36 patients pills were given by quack and in 47 patients pills were bought directly from pharmacist without any prescription on advice of friends and relatives. In only $11(11.7 \%)$ cases patient seeked nurses and for medical abortion. 
Table - IV Major complaints (n=94)

\begin{tabular}{|l|l|l|}
\hline & No. & $\%$ \\
\hline Pain in abdomen & 19 & 20.21 \\
\hline Bleeding per vaginum & 41 & 43.62 \\
\hline Passage of products of conception & 29 & 30.85 \\
\hline Fainting & 5 & 5.32 \\
\hline
\end{tabular}

Table IV shows presenting symptoms. Majority $41(43.62 \%)$ of women had complaint of bleeding per vaginum and 29 (30.85\%) women had history of passing of products of conception.

Table - V Outcome $(n=94)$

\begin{tabular}{|l|c|l|}
\hline & No. & $\%$ \\
\hline Incomplete abortion & 54 & 57.45 \\
\hline Complete abortion & 18 & 19.15 \\
\hline Missed abortion & 11 & 11.7 \\
\hline Septic abortion & 4 & 4.26 \\
\hline Live pregnancy & 6 & 6.38 \\
\hline Ectopic pregnancy & 1 & 1.06 \\
\hline
\end{tabular}

Table $\mathrm{V}$ shows the details of outcome. On Ultrasonography (USG), 54(57.45\%)women had incomplete abortion, 6(6.38\%)women had intrauterine gestational sac with cardiac activity, $18(19.15 \%)$ women had complete abortion ,1 was diagnosed to be ectopic pregnancy and $11(11.7 \%)$ woman had missed abortion.

Table-VI Complication ( $\mathrm{n}=94)$

\begin{tabular}{|l|l|l|}
\hline & No. & $\%$ \\
\hline Moderate anaemia & 43 & 45.75 \\
\hline Severe anaemia & 11 & 11.7 \\
\hline Shock & 4 & 4.26 \\
\hline Septicemia & 3 & 3.19 \\
\hline TOTAL & 61 & 64.9 \\
\hline
\end{tabular}

As shown in Table VI , 61(64.9\%) had complications, more than half women 43(45.75 $\%)$ had moderate anaemia and 11(11.7\%) had severe anaemia. Shock was present in 4(4.26\%) women on admission. Septicemia was present in 3 (3.19\%) women. Appropriate management of complication was done. Blood transfusion was needed in $19(20.21 \%)$ patients.

\section{DISCUSSION}

In India, when the MTP act was passed to legalize abortion, it was assumed that unsafe and illegal abortions would not take place and so morbidity/mortality associated with it would be prevented. $\mathrm{WHO}^{2}$ stated medical methods of abortion have been proven to be safe and effective when practiced under medical supervision. Medical abortion accounted for majority of all nonhospital abortions and it has a definite impact on reproductive freedom as it gives the woman more freedom and privacy and has become more common in both legal and illegal procedures. The guidelines $^{6}$ for medical abortion in India have been prepared by WHO-CCR in human reproduction, All India Institute of Medical Sciences, in collaboration with Ministry of Health \& Family Welfare, Government of India and Indian Council of Medical Research to assist all those who provide medical abortion services under the MTP Act and ensure safe usage for early medical abortion in India.

Counseling, careful history taking and clinical examination is must. Pregnancy confirmation for its gestational age and location is also very important and where available, urine test for pregnancy and an USG examination for confirmation of intra uterine pregnancy along with the exact gestational age should be done in all cases. Laboratory tests such as haemoglobin level, blood group and rhesus ( $\mathrm{Rh}$ ) typing, and screening for hepatitis, human immunodeficiency virus (HIV), and sexually Transmissible Infections (STIs), may be offered on the basis of individual risk factors or available resources. After formal consent, tablets are to be taken under medical supervision. The patient is asked to report immediately if excessive bleeding, pain, fainting or any problem occurs. On third visit at 15 th day, clinical history and pelvic examination should be done to ensure that there are no complications and abortion is complete. USG is required if history and examination do not confirm expulsion of products of conception. If woman is still having 
irregular bleeding, surgical curettage may be required.

In our study the incidence of self medical abortion was $29.1 \%$ among patients. $88.83 \%$ women were multiparous which was similar to studies by Giri et $\mathrm{al}^{7}(83 \%)$, Mishra et $\mathrm{al}^{8}(78 \%)$, Thaker et $\mathrm{al}^{9}(89.1 \%)$. This explain that women prefer to terminate pregnancy rather than prevent it.

Recommendation on medical abortion has been upto 9 weeks. In our study $24.47 \%$ of women took pills between 9-12 weeks and $15.96 \%$ took after 12 weeks. Similar to study of Giri et al ${ }^{7} 19 \%$ patients used pills in between 9-12 weeks and $21 \%$ after 12 weeks. Women take abortion pill whatever may be the gestational age and are not aware of possibility of serious life threatening condition like ectopic pregnancy. Studies indicate that the complications of second trimester medical abortion when compared with first trimester medical abortion are high with an increased risk of bleeding, sepsis and surgical evacuation ${ }^{10}$.

In our study, $57.45 \%$ of the patients had incomplete abortion, $6.38 \%$ had continued live pregnancy, $4.26 \%$ presented with septic abortion and $1.06 \%$ had ectopic pregnancy. Similar to our study, Nivedita et $\mathrm{al}^{11}$ reported that the rate of incomplete abortion was $62.5 \%$, septic abortion $7.5 \%$ and also Thaker et $\mathrm{al}^{9}$ reported rate of incomplete abortion $(70.2 \%)$, live pregnancy $(10.8 \%)$, ectopic pregnancy $(5.4 \%)$.

In present study, because of unsupervised medication and erratic drug schedule, many women had excessive bleeding per vaginum. In our country where $59 \%$ of pregnant women are anaemic and prevalence of mild (26\%), moderate $(31 \%)$ \& severe $(2 \%)$ anaemia is greater among pregnant women ${ }^{12}$, such bleeding added fuel to fire. In present study, moderate and severe anaemia was present in 43(45.75\%) women and $11(11.7 \%)$ women respectively. For which blood and blood products were used. Similar results were seen in studies of Giri et $\mathrm{al}^{7}$, severe anaemia in $12 \%$ and moderate anaemia in $30 \%$ also in study of Thaker et $\mathrm{al}^{9}$, moderate anaemia in $56.7 \%$ and severe anaemia in $13.5 \%$. In a study of
Hausknecht ${ }^{13}$,80,000 patients over 18 months, 13 patients required blood transfusion that is $0.01 \%$, when the drugs were given under medical supervision. In a study by Deshpande $\mathrm{S}$ et $\mathrm{al}^{14}$, no women required a blood transfusion when drugs are given under medical supervision. Haemorrhage requiring transfusions occur in only about 1 in 1000 cases of medical abortions ${ }^{15}$ when the drugs are given under medical supervision. In our study blood and blood products were used in $20.21 \%$, which is similar to studies of Ojha et $\mathrm{al}^{16}(23 \%)$ and Thaker et $\mathrm{al}^{9}(16.2 \%)$.

In this study, there were $4.26 \%$ cases of septic abortion. Similarly Ojha et $\mathrm{al}^{16}$ reported the incidence of infection after self administration of abortion pills as $3.5 \%$. In another study conducted by Bajwa et $\mathrm{al}^{17}$ the incidence of sepsis was $6.54 \%$ following medical abortion which was similar to our study. According to $\mathrm{WHO}^{18}, 47000$ women die from complications of unsafe abortion each year.

In present study, true drug failure was present in $6(6.38 \%)$ women where USG revealed intrauterine pregnancy with gestational age of 7 weeks, 9 weeks, 11 weeks and 14 weeks along with cardiac activity. Out of them 5 women opted for surgical curettage and 1 woman wanted to continue the

Pregnancy, risk of teratogenesis was explained to her. When the drug is given under medical supervision, $<1 \%$ of women can have true drug failure $^{2}$ In a study by Deshpande $S$ et $\mathrm{al}^{14}$ complete abortion occurred in $99.1 \%$ having < 49 days of amenorrhoea. Other Studies ${ }^{19}$ reported rates of $2-10 \%$ which require surgical abortion: In present study, there were one $(1.06 \%)$ women were reported having ectopic pregnancy who came to the hospital with chief compliant of fainting. Emergency laparotomy was performed. Four another woman who had taken the abortion pill had a bout of excessive bleeding came to us in shock.

According to the Consortium on National Consensus for Medical Abortion in India ${ }^{20}$, every year 20,000 women die every year due to abortion 
related complications. Most abortion-related maternal deaths are attributable to illegal abortions. In countries where the women have access to safe abortion services, their likelihood of dying as a result of an abortion is no more than one per 2,00,000 procedures. Complications of self medicated abortion have negative influence on women's future reproductive life and it places a significant financial burden on public health care system. Effect of maternal death is reflected in the family, as children lose their mother. Hence, medical abortions are safe when carried out under medical supervision. But, when it is practiced without medical supervision, morbidity and mortality are manifold.

\section{CONCLUSION}

Health care and health protection is every woman's reproductive right. The price that women pay simply for being women is unfortunately a nightmare which is appallingly true. Every woman must be counseled regarding advantages, drawbacks, risks and limitations of different methods of abortion. Prevention of unwanted pregnancy is the best way to prevent unsafe abortion. Hence, awareness on contraceptives and emergency contraceptives is must for all. The Government must stop over the counter sell of drugs that are used for medical abortion and provision should be made to make these drugs available directly from hospital/ practitioner who are qualified under the MTP act for safe $\&$ justified use of such drugs. On basis of study we can conclude that over the counter abortifacients drugs should be discouraged and banned because of irrational use \& associated complications so that women can think about care not crime. Abortion is silent screan, we have to encourage safe practise like MTP by either medical or surgical means "TO MEET THE UNMET NEEDS OF WOMEN'S HEALTH" in this aspect.

\section{REFERENCES}

1. Ahman E, Shah IH. New estimates and trends regarding unsafe abortion mortality. Int J Gynaecol Obstet. 2011;115(2):121-6.

2. International Consensus Conference on Non-surgical (Medical) Abortion in Early First Trimester on Issues Related to Regimens and Service Delivery (2006). Frequently asked clinical questions about medical abortion. Geneva: World Health Organization.ISBN 92-4-159484-5.

3. Ellertson C, Waldman SN. The Mifepristone- Misoprostol regimen for early medical abortion. Curr Women Health Rep. 2001; 1:184-90

4. The Medical Termination of Pregnancy Act, 1971, Act No. 34 of 1971, as amended by Act No. 64 of 2002

5. Geeta G, Ashutosh G, Shahshi K et al. A study of Septic Abortions: trends in a tertiary hospital. J Obstet Gynecol India.2005; 55(3): 257-260.

6. Guidelines for medical abortion in indiaMaterial circulated by CASSA during the State-level Workshop on "Review of MTP Act 1971 in the context of Women's Right to Safe Abortion and Halting Sex Selective Abortion, held in Chennai on $17^{\text {th }}$ and $18^{\text {th }}$ August 2007.

7. Giri A, Srivastav VR, Suwal A, Sharma B et al. A Study of Complications following Self-administration with Medical Abortion Pills.NJOG / VOL 10 / NO. 1 / ISSUE 19/ Jan-Jun, 2015.

8. Mishra N. Unprecedented use of medical abortion can be injurious to health. JEMS. 2013;2(8):856-9.

9. Thaker RV, Deliwala KJ, Shah PT. Selfmedication of abortion pill: women`s health in Jeopardy. NHLJMS. 2014;3:2631.

10. Maarit J, Maarit N, Satu S, Elina H, Mika $\mathrm{G}$, Oskari H. Immediate adverse events after second trimester medical termination 
of pregnancy. Hum Reprod.

2011;26(4):927-32.

11. Nivedita K, Fatima S. Is it safe to provide abortion pills over the counter? A study on outcome following self medication with abortion pills. J Clin Diagn Res. 2015;9(1):1-4.

12. NFHS - 3 National Family Health Survey.

13. Hausknecht R. Mifepristone \& Misoprostol for early medical abortion: 18 months experience in United States. Contraception 2003; 67: 463-5.

14. Deshpande S, Yelikar K, Deshmukh A Kanade K. Comparative study of medical abortion by Mifepristone with vaginal Misoprostol in women < 49 days versus 50-63 days of amenorrhoea. J of Obst \& Gyn of India. 60(5);2010: 403-407.

15. Grimes DA. Medical abortions in early pregnancy: A review of the evidence. Obstet Gynecol 1997;89: 790-96.

16. Ojha N, Bista KD. Situation analysis of patients attending TU Teaching Hospital after medical abortion with problems and complications. JNMA. 2013;52(191):46670.

17. Bajwa SK, Bajwa SS, Ghai GK, Singh N, Singh A, Goraya SPS. Medical abortion: is it a blessing or curse for the developing nations? SLJOG. 2011;33:84-90.

18. Sedgh $G$ et al., Induced abortion: incidence and trends worldwide from 1995 to 2008, Lancet, 2012, 379(9816):625-632

19. Trupin S R, Moreno C. Medical Abortion: Overview \& Management. Medscape Womens Health 2001; 6: 4.

20. India - ICMA International Consortium for Medical Abortion. m.icma.md/country/IN. 